\title{
Analisa Pengecekan Peralatan Arrester Menggunakan Thermovisi pada Bay Indarung 1 Gardu Induk Pauh Limo
}

\author{
Rafika Andari ${ }^{1}$, Sitti Amalia ${ }^{2}$, Ezi Azhari ${ }^{3}$ \\ Submission: 27-11-2019, Accepted: 08-07-2020
}

\begin{abstract}
The hot points that occur in the switchyard are caused by currents flowing in the conductor due to obstacles. The frequent heating part is the terminal and connection portion of the switchyard, especially between the two different metals, as well as the cross section of the conductor that shrinks due to corrosion. So that the part should be considered, by controlling or checking the temperature using Thermovisi. The hot temperature of equipment Arrester in Bay Indarung 1 Pauh Limo is still under normal conditions where the temperature ranges from $20^{\circ} \mathrm{C}-43^{\circ} \mathrm{C}$. But need attention to the improvement plan. Temperature difference between the phase of Arrester equipment in switchyard of Bay Indarung 1 Pauh Limo one reaches the III condition, there are conditions I and II where it shows necessary investigation and improvement plan, to avoid occurrence short-circuited between phases $(R, S, T)$.
\end{abstract}

Intisari-Pemanasaan (hot point) yang terjadi pada peralatan Gardu Induk (switchyard) disebabkan oleh arus yang mengalir dalam konduktor akibat adanya hambatan. Bagian yang sering mengalami pemanasan adalah bagian terminal dan sambungan pada switchyard, terutama antara dua logam yang berbeda, serta penampang konduktor yang mengecil karena korosi. Sehingga bagian tersebut harus diperhatikan, dengan cara melakukan pengontrolan atau pengecekan suhunya menggunakan thermovisi. Suhu panas peralatan Arrester pada Bay Indarung 1 Gardu Induk Pauh Limo masih berada pada kondisi normal dimana suhunya berkisar antara $20^{\circ} \mathrm{C}-43^{\circ} \mathrm{C}$. namun perlu perhatian untuk rencana perbaikan. Selisih suhu antar fase peralatan Arrester pada Bay Indarung 1 Gardu Induk Pauh Limo tidak ada yang mencapai kondisi III, namun ada terdapat kondisi I dan II sehingga perlu dilakukan investigasi dan rencana perbaikan, untuk menghindari terjadinya hubung singkat antar fase $(\mathbf{R}, \mathbf{S}, \mathbf{T})$.

Kata Kunci-gardu induk, arrester, thermovisi

\section{PENDAHULUAN}

PT. PLN merupakan salah satu instrument pembangunan di Indonesia yang sangat penting, baik oleh pemerintah maupun juga oleh masyarakat luas.

\footnotetext{
1,2 Dosen, Program Studi Teknik Elektro Insitut Teknologi Padang. Jalan Gajah Mada kandis Nanggalo, Kota Padang (Telp. 0751-7051355; fax 0751-4444842; e-mail ${ }^{1}$ rafika.andari09@gmail.com, ${ }^{2}$ sittiamalia23213059@gmail.com)

${ }^{3}$ Mahasiswa, Program Studi Teknik Elektro Insitut Teknologi Padang. Jalan Gajah Mada kandis Nanggalo, Kota Padang (Telp. 0751-7051355; fax 0751-4444842)
}

Seiring dengan perkembangan era digital pada berbagai bidang termasuk pada peralatan listrik, PT. PLN pun sudah menggunakan peralatan digital di Gardu Induk (GI) Pauh Limo. Peralatan digital ini digunakan untuk pengecekan berbagai keadaan yang terjadi pada peralataan listrik, termasuk suhu pada Arrester.

Dalam pengoperasiannya, saat peralatan gardu induk (switchyard) menghantarkan arus listrik maka akan terjadi suhu panas atau hot point karena kerugian arus mengalir dalam konduktor yang disebabkan oleh adanya hambatan. Akibat banyaknya peralatan yang sudah berusia tua dan jarak antar-switchyar yang berdekatan, sering terjadinya gesekan sehingga rawan muncul hot point. bagian yang sering mengalami pemanasaan adalah bagian terminal dan sambungan pada switchyard, terutama antara dua logam yang berbeda, serta penampang konduktor yang mengecil karena korosi [1]. Sehingga bagian tersebut harus diperhatikan, yaitu dengan cara melakukan pengontrolan atau pengecekan. Peralatan digital yang digunakan untuk pengecekan hot point adalah thermovisi.

Berdasarkan hal tersebut pengecekan hot point sangat penting untuk dilakukan, karena jika tidak dilakukan pengecekan akan terjadi hubung singkat. Pada penelitian ini penulis melakukan pengecekan untuk mengetahui kondisi hot point pada peralatan Bay Indarung 1 dengan menggunakan thermovisi dengan cara menganalisa hasil evaluasi selisih suhu antar fasa $(\Delta t)$ berdasarkan Standar NETA MTS-1997.

\section{LANDASAN TEORI}

A Gardu Induk

Gardu Induk (GI) merupakan bagian dari sistem penyaluran (transmisi) tenaga listrik, atau merupakan satu kesatuan dari sistem penyaluran (transmisi) [2]. Gardu induk Pauh Limo Padang merupakan jenis gardu induk konvensional yang sebagian besar komponennya ditempatkan di luar gedung, beberapa diantaranya seperti komponen kontrol, sistem proteksi dan sistem kendali serta komponen bantu lainnya, ditempatkan di dalam gedung seperti terlihat pada Gambar 1.

Gardu Induk memiliki beberapa fungsi, yaitu :

a. Mentransformasikan tenaga listrik tegangan tinggi yang satu ketegangan yang lainnya atau tegangan menengah. 


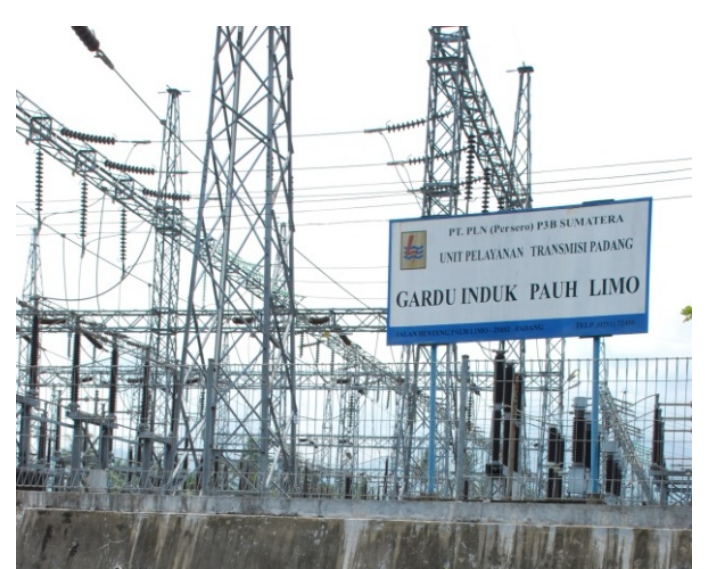

Gambar 1. Gardu Induk Pauh Limo

b. Pengukuran, pengawasan, operasi serta pengaturan pengamanan dari sistem tenaga listrik.

c. Pengaturan daya ke gardu-gardu lainnya melalui tegangan tinggi dan gardu distribusi melalui feeder tegangan menengah [3].

Peralatan utama yang terdapat pada gardu induk

Pauh Limo adalah sebagai berikut:

1) Transformator Daya

2) Pemisah Tegangan ( PMS)

3) Pemutus Tegangan

4) Transformator Instrumental :

a. Transformator Arus ( CT )

b. Transformator Tegangan (PT)

5) Lightning Arrester ( LA )

6) Busbar ( Rel Daya )

7) Isolator

8) Cubicle

9) Relay

10) Peralatan kontrol :

a.Panel Pemakaian Sendri

b. Panel Rele

c. Alat Ukur

11) Peralatan Lainnya :

a. Neutral Ground Resistor

b. Static Capacitor

c. Baterai

d. Rectifier

e. Peralatan Telekomunikasi

Sistem kelistrikan gardu induk Pauh Limo memiliki interkoneksi dengan beberapa gardu induk lainnya dalam wilayah tragi padang dan pembangkit PLTG pauh limo.gardu induk tersebut lain:
a. GIS simpang Haru
b. Gardu induk indarung
c. Gardu induk pauh limo
d. Gardu induk bungus
e. Gardu induk kambang
f. Gardu induk taluk sirih
g. Gardu induk solok

Adapun pembagian tegangan pada sistem kelistrikan

GI Pauh Limo adalah sebagai berikut:

1) sistem $150 \mathrm{kV}$
Sistem jaringan $150 \mathrm{kV}$ merupakan sistem jaringan transmisi antara satu gardu induk dengan gardu induk lain dengan pusat pembangkit tenaga listrik.

2) Sistem $20 \mathrm{kV}$

Sistem $20 \mathrm{kV}$ merupakan sistem jaringan distribusi tegangan menengah yang digunakan pada sistem jaringan distribusi primer dan untuk pemakain sendiri melalui beberapa feeder-feeder $20 \mathrm{kV}$ yang terdapat pada gardu induk pauh limo terdiri dari beberpa feeder, yaitu :

a feeder 1, digunakan untuk pemakain sendiri

b feeder 2, untuk distribusi daya ke daerah kuranji

c feeder 3, untuk distribusi daya ke daerah koto tingga

d feeder 4, untuk distribusi daya ke daerah bungus 1

e feeder 2, untuk distribusi daya ke daerah bungus 2

f feeder 2, untuk distribusi daya ke daerah BLK

$\mathrm{g}$ feeder 2, untuk distribusi daya ke daerah kandis 1

$\mathrm{h}$ feeder 2, untuk distribusi daya ke daerah kandis 2

i feeder 2, untuk distribusi daya ke daerah indarung 1 .

j feeder 2, untuk distribusi daya ke daerah indarung 2 .

$\mathrm{k}$ feeder UNAND.

1 feeder limau manis.

$\mathrm{m}$ feeder belimbing.

3) Sistem $110 \mathrm{~V} \mathrm{DC}$

Tegangan $110 \mathrm{~V}$ DC ini diperoleh melalui rectifier dan baterai. Umumnya digunakan sebagai suplai rele-rele proteksi yang terdapat pada ruangan kontrol gardu induk Pauh Limo. Tegangan ini dapat diperoleh melalui dua cara, yaitu melalui rectifier ketika tidak ada gangguan sistem kelistrikan pada gardu induk dan ketika terjadi gangguan yang mengharuskan melakukan pemadaman diperoleh melalui baterai sehingga suplai daya tidak berhenti mengalir untuk beberapa peralatan proteksi gardu induk.

4) Sistem $380 \mathrm{~V}$ AC

Tegangan listrik380 V AC memiliki tiga fasa tegangan yang diperoleh dengan mentransformasikan tegangan 20 KV pada sisi feeder pemakaian sendiri. Tegangan ini biasa digunakan pada tegangan listrik dengan daya yang lebih besar seperti peralatan-peralatan listrik industri.

\section{B Lightning Arrester (LA)}

Lightning Arrester (LA) disingkat Arrester merupakan alat pelindung bagi instalasi listrik dan peralatan listrik terhadap tegangan lebih yang disebabkan oleh surja petir atau surja hubung. LA ini bertindak sebagai jalan pintas (By Pass) disekitar isolasi dengan membentuk jalan untuk memudahkan arus melalui sambaran petir sehingga tidak timbul tegangan lebih yang tinggi pada peralatan [4].

Arrester memiliki fungsi yang berbeda sesuai dengan keadaan tegangan. Ia akan berfungsi sebagai isolasi pada tegangan normal, namun ketika terjadi surja petir yang mengakibatkan tegangan lebih, maka arrester akan berfungsi sebagai penghantar dengan cara mengalirkan arus yang tinggi ke tanah [5]. Untuk itulah, LA digunakan untuk mengurangi tegangan surja dengan cara mengalirkan arus surja ke tanah dalam orde yang sangat kecil, sehingga pengaruh follow current tidak ikut serta diketanahkan [6]. 
Konstruksi LA pada saluran transmisi memiliki persamaan dengan LA pada gardu induk, seperti terlihat pada Gambar 2.

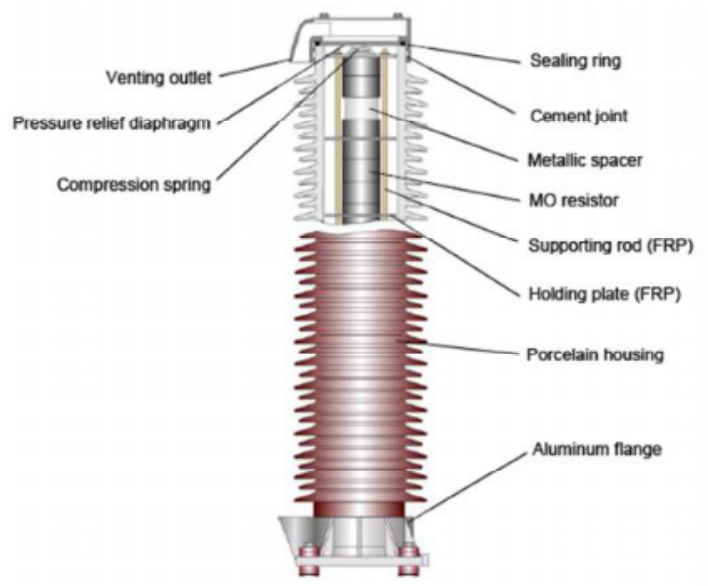

Gambar 2. Konstruksi LA ${ }^{[1]}$

Adapun komponen utama LA adalah varistor yang merupakan komponen aktif umumnya terbuat dari Zinc Oxide $(\mathrm{ZnO})$. Penggunaan varistor adalah untuk melindungi sistem tenaga listrik dari ancaman tegangan lebih akibat terjadinya petir atau akibat dari proses hubung singkat sistem tenaga listrik.

Varistor $\mathrm{ZnO}$ memiliki beberapa kelebihan dibandingkan dengan varistor lainnya, yaitu dengan ukuran yang kecil mampu menyerap energi yang tinggi, responsif terhadap gelombang datang yang cepat, penggunaan yang lebih awet pada kondisi lingkungan yang buruk serta memiliki biaya yang relatif murah [7].

Bagian-bagian penting Arrester terdiri atas:

1) Elektroda atau Terminal

Terdapat dua jenis elektroda yaitu bagian atas dihubungkan dengan saluran bertegangan sedangkan bagian bawah dihubungkan ke ground atau pentanahan.

2) Sela percik merupakan bagian pada arrester yang dapat menahan tegangan atau menjadi isolator dalam kondisi operasional. Apabila terjadi tegangan lebih, maka terjadi breakdown pada spark gap sehingga berubah menjadi konduktor.

3) Tahanan Katup

Tahanan yang difungsikan untuk menghilangkan potensi terjadi nya arus susulan, ketika arrester telah mengalirkan petir ketanah.

4) Housing

Bagian luar/selubung yang berfungsi sebagai pelindung bagaian dalam. Housing biasanya terbuat dari kaca, porselen, campuran keramik silikon dan lain-lain.

5) Counter

Counter berfungsi sebagai alat penghitung jumlah kerja arrester.

Rafika Andari: Analisa Pengecekan Peralatan Arrester ...

\section{SURGE ARRESTER}

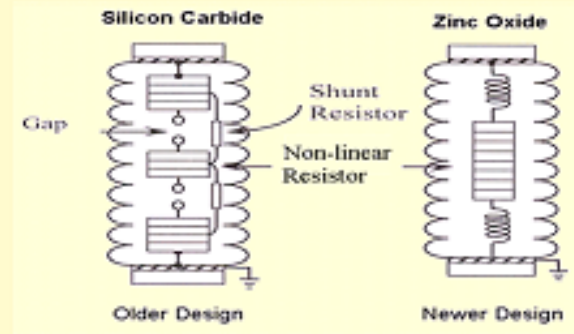

Gambar 3. Bagian-bagian Arrester[8]

Penghubung dan Konduktor pada Arrester terdiri dari beberapa penghubung, yakni Dead end clamp line, konduktor, klem, Isolator dan kawat ground.

a. Dead end clamp line

Dean end clamp seperti terlihat pada Gambar 4. Berfungsi sebagai penghubung konduktor untuk menghantarkan arus listrik sehingga dapat memaksimalkan penggunaan jaringan.

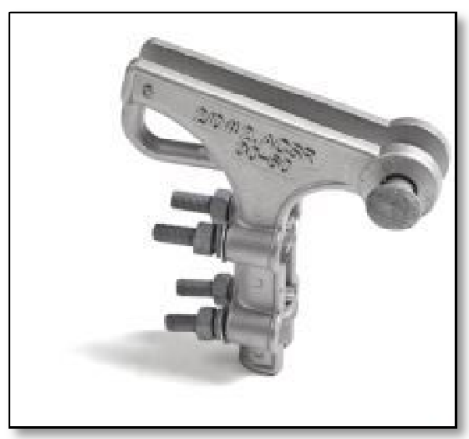

Gambar 4. Dean end clamp

b. Konduktor

Konduktor merupakan material yang dapat menghantarkan arus listrik, umumnya material berbahan logam, seperti tembaga, alumunium, tembaga dan lain sebagainya.

c. Klem

Klem seperti pada Gambar 5, yang berfungsi untuk menopang kabel-kabel dan kabel tersebut pun bisa terpasang dengan kuat serta tidak terlepas.

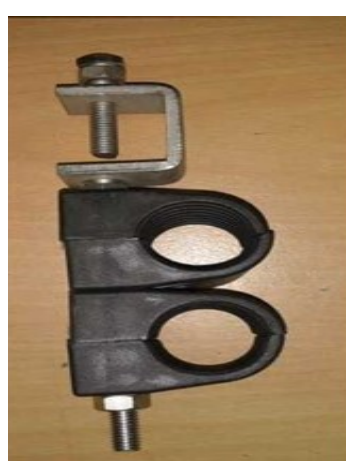

Gambar 5. Klem

p-ISSN:1693 - 2951; e-ISSN: 2503-2372 
d. Isolator

Isolator merupakan material yang bersifat sebagai penghambat atau isolasi. Material ini tidak dapat mengahantarkan arus listrik, yaitu berbahan dasar selain dari logam seperti keramik, kaca dan plastik.

e. Kawat ground

Kawat ini berfungsi sebagai pelindung kawat fasa saat terjadinya sambaran petir, serta meneruskan arus berlebih ke tanah.

\section{Thermovisi}

Salah satu alat yang dapat digunakan untuk memvisualisasikan dan mendeteksi suhu pada suatu objek adalah thermovisi. Suhu dari suatu objek di tangkap dan di tampilkan ke sebuah display menggunakan teknologi inframerah. Panas yang lebih tinggi (hot point) akan dihasilkan pada saat tahanan kontak lebih besar dari tahanan konduktor, sehingga arus listrik yang mengalir semakin besar pada penghantar. Beberapa hal yang dapat mempengaruhi keadaan tahanan kontak yaitu, kebersihan bidang kontak sambung, pemasangan baut pengikat, kerapatan pengepresan, dan perbedaan bahan pada bidang sambungan [9].

Pengukuran suhu pada Gardu Induk Pauh Limo menggunakan alat Infrared Thermovisi FLIR E6. Pengukuran dilakukan dari jarak jauh tanpa menyentuh objek, dengan prinsip bahwa semua objek memancarkan energi berupa inframerah. Suhu objek yang semakin panas menandakan molekulnya semakin aktif sehingga energi inframerah yang dipancarkannya akan semakin banyak pula. Thermovisi ini dapat menghasilkan pengukuran suhu yang lebih akurat diabandingkan alat lainnya [10].

\section{Metodelogi PENELITIAN}

\section{A. Langkah Pengambilan Gambar Thermal:}

1. Masukkan baterai ke dalam kompartemen baterai di kamera

2. Masukkan kartu memori pada slot memori di kamera

3. Tekan tombol untuk menyalakan kamera

4. Tunggu sampai proses startup atau loading selesai

5. Aturlah nilai-nilai parameter sesuai dengan objek yang akan diamati dan kondisi lingkungan

6. Pilih alat pengukuran yang akan digunakan misalnya, spot atau box (area)

7. Arahkan kamera pada objek yang akan diamati

8. Mengatur fokus dengan memutar focus ring

9. Tekan tombol Save untuk menyimpan gambar

10. Jalankan perangkat lunak FLIR Tools pada komputer (Install jika belum ada dikomputer)

11. Gunakan kabel USB untuk mengoneksikan kamera dengan komputer

12. Pindahkan gambar yang telah diambil ke FLIR Tools untuk kemudian dilakukan analisadan membuat laporan

B. Tips dalam pengambilan Gambar Thermal:

1. Pastikan Anda aman

2. Fokus

3. Pilih range temperatur yang benar

4. Komposisi gambar atau penempatan objek pada layar

5. Minimalisir efek pantulan
6. Pilih latar belakang sesederhana mungkin

7. Pilih sudut pengambilan yang benar

8. Pilih area yang memiliki emisivitas tinggi untuk melakukan pengukuran

9. Peganglah kamera dengan stabil

\section{Bagian-bagian Layar}

Bagian - bagian layar pada thermovisi dapat dilihat pada gambar 6.

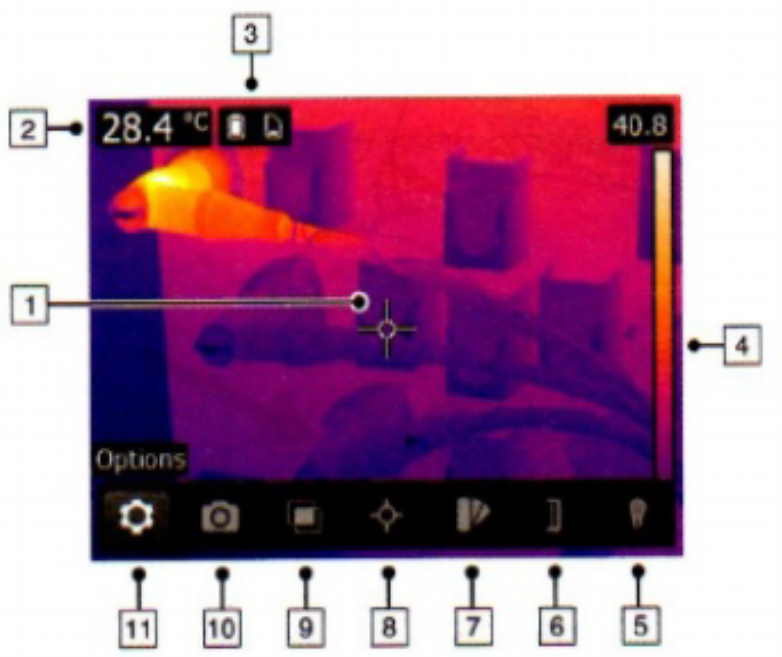

Gambar 6. Bagian-Bagian Layar Thermovisi Keterangan:

1. Alat Ukur (misalnya spotmeter)

2. Hasil Pengukuran

3. Ikon status dan pemberitahuan

4. Skala suhu

5. Tombol toolbar lampu

6. Tombol toolbar skala suhu

7. Tombol toolbar warna

8. Tombol toolbar pengukuran

9. Tombol toolbar model gambar

10. Tombol toolbar perekaman

11. Tombol toolbar pilihan

Catatan: Untuk menampilkan sistem menu, sentuh layar atau tekan tombol navigasi.

Dalam pengukuran menggunakan Thermovisi ada dua hal yang perlu diperhatikan berdasarkan pada STANDAR NETA, yaitu :

1. Membandingkan hasil ukur, dengan suhu operasi objek

2. Membandingkan hasil ukur dengan objek lain yang sama disekitarnya.

Objek lain yang sama yakni objek yang memiliki bentuk yang sama tetapi ukuran atau lokasi yang berbeda. Standar yang digunakan untuk menentukan suhu objek adalah sebagai berikut:

a. Kondisi normal

$0^{\circ} \mathrm{C}-10^{\circ} \mathrm{C}$ : Kondisi baik

$10^{\circ} \mathrm{C}-25^{\circ} \mathrm{C}$ : Periksa saat pemeliharaan

$25^{\circ} \mathrm{C}-40^{\circ} \mathrm{C}$ : Rencana Perbaikan (max 30 hari)

b. Kondisi tidak normal

$40^{\circ} \mathrm{C}-70^{\circ} \mathrm{C}$ : Perbaiki segera

$70^{\circ} \mathrm{C} \quad$ : kondisi darurat 
Dari hasil pengukuran suhu dengan thermovisi, akan dapat diketahui kondisi perbandingan suhu antar fase $(\Delta T)$ seperti dapat dilihat pada tabel 1. yang mengacu pada Standar NETA MTS-1997 berdasarkan pada buku PLN SK DIR 5202014.

TABEL I

KONDISI PERBANDINGAN SUHU ANTAR FASE $(\Delta T)$ BERDASARKAN STANDAR NETA MTS-1997

\begin{tabular}{|c|l|c|}
\hline Kondisi & \multicolumn{1}{|c|}{ Justifikasi } & \multicolumn{1}{c|}{ Suhu } \\
\hline Kondisi I & $\begin{array}{l}\text { Dimungkinkan } \\
\text { adanya } \\
\text { ketidaknormalan, } \\
\text { perlu investigasi } \\
\text { lanjut }\end{array}$ & $1^{0} \mathrm{C}<\Delta T \leq 3^{0} \mathrm{C}$ \\
\hline Kondisi II & $\begin{array}{l}\text { Mengindikasikan } \\
\text { adanya defesiensi, } \\
\text { perlu dijadwalkan } \\
\text { perbaikan }\end{array}$ & $4^{0} \mathrm{C}<\Delta T \leq 15^{0} \mathrm{C}$ \\
\hline Kondisi III & $\begin{array}{l}\text { Ketidaknormalan } \\
\text { mayor, perlu } \\
\text { dilakukan } \\
\text { perbaikan segera }\end{array}$ & $\Delta T>16^{0} \mathrm{C}$ \\
\hline
\end{tabular}

Catatan :

a. Jika suhu maximum kepala Bushing $\geq 90^{\circ} \mathrm{C}$ segera Lakukan investigasi penyebab

b. Jika selisih suhu antar fase $(\Delta \mathrm{t})$ lebih kecil dari satu maka dikategorikan dalam keadaan normal.

\section{HASIL DAN PEMBAHASAN}

Pengecekan Arrester menggunakan Thermovisi dilakukan pada minggu kedua dan minggu keempat bulan Juli 2019. Peralatan yang diukur suhunya meliputi Dead End Clamp Line, Konduktor Dead End Clamp Line, Klem Junction Konduktor LA, Konduktor Junction, Isolator, dan kawat Ground LA. Pengecekan untuk mendapatkan nilai Fase R, S, dan T sebagaimana dapat dilihat pada Tabel 2.

a. Dead End Clamp Line

Fase R - S = 35,6-32,0 = 3,6

Justifikasi kondisi: II

Mengindikasikan adanya defesiensi, dan perlu dijadwalkan perbaikan

Fase $\mathrm{S}-\mathrm{T}=35,6-35,8=0,2$

Justifikasi kondisi: Normal

Fase $\mathrm{T}-\mathrm{R}=35,8-32,0=3,8$

Justifikasi kondisi: II

Mengindikasikan adanya defesiensi, dan perlu dijadwalkan perbaikan

b. Konduktor Dead End Clamp Line

Fase R - S = 23,6 - 30,3 = 6,7

Justifikasi kondisi: II

Mengindikasikan adanya defesiensi, dan perlu dijadwalkan perbaikan

Fase $\mathrm{S}-\mathrm{T}=30,3-27,3=3$

Justifikasi kondisi: II

Rafika Andari: Analisa Pengecekan Peralatan Arrester ...
105

Mengindikasikan adanya defesiensi, dan perlu dijadwalkan perbaikan

Fase $\mathrm{T}-\mathrm{R}=27,3-23,6=3,7$

Justifikasi kondisi: II

Mengindikasikan adanya defesiensi, dan perlu dijadwalkan perbaikan

TABEL II

PENGUJIAN ARRESTER MENGGUNAKAN THERMOVISI PADA MINGGU KE-2 DAN KE-4 BULAN JULI 2019

\begin{tabular}{|c|c|c|c|c|c|c|c|}
\hline \multirow{2}{*}{$\begin{array}{l}\mathbf{N} \\
\mathbf{0 .}\end{array}$} & \multirow{2}{*}{ URAIAN } & \multicolumn{3}{|c|}{$\begin{array}{c}\text { Suhu }\left({ }^{\circ} \mathrm{C}\right) \text { Minggu } \\
\text { ke-2 }\end{array}$} & \multicolumn{3}{|c|}{$\begin{array}{c}\text { Suhu }\left({ }^{\circ} \mathrm{C}\right) \text { Minggu } \\
\text { ke-4 }\end{array}$} \\
\hline & & $\mathbf{R}$ & $\mathbf{S}$ & $\mathbf{T}$ & $\mathbf{R}$ & $\mathbf{S}$ & $\mathbf{T}$ \\
\hline 1 & $\begin{array}{l}\text { Dead End } \\
\text { Clamp line }\end{array}$ & 32,0 & 35,6 & 35,8 & 32,0 & 35,6 & 35,8 \\
\hline 2 & $\begin{array}{l}\text { Konduktor } \\
\text { Dead End } \\
\text { Clamp line }\end{array}$ & 23,6 & 30,3 & 27,3 & 23,6 & 30,3 & 27,3 \\
\hline 3 & $\begin{array}{l}\text { Klem Junction } \\
\text { Konduktor } \\
\text { Atas } \\
\end{array}$ & 37,4 & 40,8 & 37,2 & 37,4 & 40,8 & 37,2 \\
\hline 4 & $\begin{array}{l}\text { Konduktor } \\
\text { Klem Junction } \\
\text { Atas }\end{array}$ & 25,7 & 26,7 & 25,0 & 25,7 & 26,7 & 25,0 \\
\hline 5 & $\begin{array}{l}\text { Klem Junction } \\
\text { Konduktor } \\
\text { LA }\end{array}$ & 37,1 & 38,0 & 38,3 & 37,1 & 38,0 & 38,3 \\
\hline 6 & $\begin{array}{l}\text { Konduktor } \\
\text { Junction } \\
\text { Konduktor } \\
\text { LA }\end{array}$ & 36,5 & 35,5 & 33,0 & 36,5 & 35,5 & 33,0 \\
\hline 7 & $\begin{array}{l}\text { Konduktor } \\
\text { LA }\end{array}$ & 35,7 & 38,1 & 37,2 & 35,7 & 38,1 & 37,2 \\
\hline 8 & Klem LA & 34,7 & 35,9 & 38,4 & 34,7 & 35,9 & 38,4 \\
\hline 9 & $\begin{array}{l}\text { Isolator LA } \\
\text { Atas }\end{array}$ & 39,3 & 42,5 & 42,7 & 39,3 & 42,5 & 42,7 \\
\hline 10 & $\begin{array}{l}\text { Isolator LA } \\
\text { Tengah }\end{array}$ & 38,8 & 40,8 & 41,6 & 38,8 & 40,8 & 41,6 \\
\hline 11 & $\begin{array}{l}\text { Isolator LA } \\
\text { Bawah }\end{array}$ & 39,1 & 41,5 & 43,1 & 39,1 & 41,5 & 43,1 \\
\hline 12 & $\begin{array}{l}\text { Kawat } \\
\text { Ground LA }\end{array}$ & 31,4 & 35,9 & 36,7 & 31,4 & 35,9 & 36,7 \\
\hline
\end{tabular}

Setelah pengecekan suhu panas pada minggu ke-2 dan ke-4, selanjutnya adalah menghitung selisih suhu Antar Fase $(\Delta t)$ yang bertujuan untuk menghindari terjadinya arus hubung singkat antar fase. Perhitungan dilakukan dengan membandingkan fase yaitu antara fase $R$ dengan $S$, fase $S$ dengan $\mathrm{T}$, dan fase $\mathrm{T}$ dengan $\mathrm{R}$. Perhitungan yang akan dipaparkan pada pembahasan ini hanya untuk dua peralatan yakni Dead End Clamp Line dan Konduktor Dead End Clamp Line. Untuk hasil perhitungan $\Delta \mathrm{t}$ dan justifikasi berdasarkan Standar NETA MTS-1997(Tabel 1.) dari semua peralatan yang telah dicek, secara lengkap dapat dilihat pada tabel 3 . 
TABEL III

PERHITUNGAN SELISIH SUHU ANTAR FASE( $\triangle$ T)PADA MINGGU KE-2 DAN KE-4 BULAN JULI 2019

\begin{tabular}{|c|c|c|c|c|c|c|c|}
\hline \multirow[t]{2}{*}{$\begin{array}{l}\mathbf{N} \\
\mathbf{0 .}\end{array}$} & \multirow[t]{2}{*}{ URAIAN } & \multicolumn{3}{|c|}{$\begin{array}{c}\text { Suhu }\left({ }^{\circ} \mathrm{C}\right) \\
\text { Minggu ke-2 dan } \\
\text { ke-4 }\end{array}$} & \multicolumn{3}{|c|}{ Kondisi } \\
\hline & & $\mathbf{R}$ & $\mathbf{S}$ & $\mathbf{T}$ & $\mathbf{R}$ & $\mathbf{S}$ & $\mathbf{T}$ \\
\hline 1 & $\begin{array}{l}\text { Dead End } \\
\text { Clamp line }\end{array}$ & 5,6 & 0,2 & 3,8 & II & $\begin{array}{l}\text { Nor } \\
\text { mal }\end{array}$ & II \\
\hline 2 & $\begin{array}{l}\text { Konduktor } \\
\text { Dead End } \\
\text { Clamp line }\end{array}$ & 6,7 & 3 & 3,7 & II & II & II \\
\hline 3 & $\begin{array}{l}\text { Klem } \\
\text { Junction } \\
\text { Konduktor } \\
\text { Atas }\end{array}$ & 3,4 & 3,5 & 0,1 & II & II & $\begin{array}{l}\text { Nor } \\
\text { mal }\end{array}$ \\
\hline 4 & $\begin{array}{l}\text { Konduktor } \\
\text { Klem } \\
\text { Junction } \\
\text { Atas }\end{array}$ & 1 & 1,7 & 0,7 & I & I & $\begin{array}{l}\text { Nor } \\
\text { mal }\end{array}$ \\
\hline 5 & $\begin{array}{l}\text { Klem } \\
\text { Junction } \\
\text { Konduktor } \\
\text { LA }\end{array}$ & 0,9 & 0,3 & 1,2 & $\begin{array}{l}\text { Nor } \\
\text { mal }\end{array}$ & $\begin{array}{l}\text { Nor } \\
\text { mal }\end{array}$ & $\mathrm{I}$ \\
\hline 6 & $\begin{array}{l}\text { Konduktor } \\
\text { Junction } \\
\text { Konduktor } \\
\text { LA }\end{array}$ & 1 & 2,5 & 3,5 & I & I & II \\
\hline 7 & $\begin{array}{l}\text { Konduktor } \\
\text { LA }\end{array}$ & 2,4 & 0,9 & 1,5 & I & $\begin{array}{l}\text { Nor } \\
\text { mal }\end{array}$ & $\mathrm{I}$ \\
\hline 8 & Klem LA & 1,2 & 2,5 & 3,5 & I & I & I \\
\hline 9 & $\begin{array}{l}\text { Isolator LA } \\
\text { Atas }\end{array}$ & 3,2 & 2,5 & 3,7 & I & $\begin{array}{l}\text { Nor } \\
\text { mal }\end{array}$ & I \\
\hline 10 & $\begin{array}{l}\text { Isolator LA } \\
\text { Tengah }\end{array}$ & 2 & 0,8 & 3,4 & I & $\begin{array}{l}\text { Nor } \\
\text { mal }\end{array}$ & I \\
\hline 11 & $\begin{array}{l}\text { Isolator LA } \\
\text { Bawah }\end{array}$ & 2,4 & 1,6 & 4 & I & $\begin{array}{l}\text { Nor } \\
\text { mal }\end{array}$ & II \\
\hline 12 & $\begin{array}{l}\text { Kawat } \\
\text { Ground LA }\end{array}$ & 4,5 & 0,8 & 5,3 & II & $\begin{array}{l}\text { Nor } \\
\text { mal }\end{array}$ & II \\
\hline
\end{tabular}

Berdasarkan perhitungan pada table 3 di atas diperoleh bahwa pengecekan dead end clamp line dikategorikan dalam kondisi normal, dimana fase R-S dan $\mathrm{T}-\mathrm{R}$ mengindikasikan adanya defesiensi, dan perlu dijadwalkan perbaikan, sedangkan konduktor dead end clamp line juga dikategorikan dalam kondisi norml, dan fase $\mathrm{R}-\mathrm{S}$, S-T dan T-R mengindikasikan adanya jadwal perbaikan, sementara pada klem dan konduktor ada beberapa selisih fase yang dikategorikan penjadwalan perbaikan dan ada beberapa berada pada kondisi normal.Sementara Isolator, diukur pada bagian atas, tengah dan bawah, setelah dihitung selisih suhunya fase R-S dan pada T-R masih perlu diinvestigasi dan jadwal perbaikan sedangkan pada S-T dalam keadaan normal. Dan terakhir pengecekan kawat ground LA, suhunya dikategorikan pada keadaan normal dan selisih suhu antar fase S-T dalam keadaan normal, sedangkan fase R-S dan T-R mengindikasikan jadwal perbaikan. Berdasarkan pengujian di atas tidak ada peralatan yang berada pada kondisi berbahaya.

\section{KESIMPULAN}

Pengukuran suhu panas (Hot point) pada peralatan dengan menggunakan thermovisi, pertama-tama adalah mempersiapkan thermovisi terlebih dahulu dengan memasukkan baterai yang telah dicas dan kartu memori pada slot memori, selanjutnya menekan tombol untuk menyalakan kamera dan menunggu sampai proses Start up. Memilih alat yang akan diukur suhunya, mengarahkan thermovisi ke objek yang akan diamati suhunya, seperti konduktor dan klem pada pada panel. Kemudian mengatur fokus dengan memutar fokus ring, menekan tombol save atau simpan gambarmenggunakan kabel USB untuk mengkoneksikan dengan komputer melalui software flir tools.

Suhu panas peralatan Arrester pada Bay Indarung 1 Gardu Induk Pauh Limo masih berada pada kondisi normal dimana suhunya berkisar antara $20^{\circ} \mathrm{C}-43^{\circ} \mathrm{C}$. namun perlu perhatian untuk rencana perbaikan.

Selisih suhu antar fase peralatan Arrester pada Bay Indarung 1 Gardu Induk Pauh Limo tidak ada yang mencapai kondisi III, namun ada terdapat kondisi I sehingga perlu dilakukan investigasi dan rencana perbaikan, untuk menghindari terjadinya hubung singkat antar fase (R,S,T).

\section{REFERENSI}

1. [1] PT. PLN (PERSERO), 2014. Himpunan Buku Pedoman Pemeliharan Primer Gardu Induk. No. 0520-2.K/DIR/2014. Jakarta.

2. [2] Yusmartato, dkk. 2017. Pembangunan Gardu Induk 150 kV di Desa Parbaba Dolok Kecamatan Pangururan Kabupaten Samosir. Journal of Electrical Technology, Vol. 2, No. 3, Oktober 2017.

3. [3] Marsudi Ditjeng. 2006. Operasi Sistem Tenaga Listrik. Erlangga: Jakarta.

4. [4] Hakim, Fahreza Abi. 2018. Analisis Kinerja Surge Arrester Terhadap Kenaikan Tegangan Akibat Sambaran Petir Di Saluran Overhead Contact System (Ocs) Kereta Rel Listrik 1500 Volt. Skripsi Fakultas Teknik Universitas Lampung.

5. [5] Avryansyah Akbar, Airlangga. 2013. Pemeliharaan Lightning Arrester (LA) Pada Gardu Induk Krapyak 150 Kv Pt. Pln (Persero) P3b Jawa - Bali App Semarang”. https://anzdoc.com/pemeliharaanlightning-arrester-la-pada-gardu-induk-krapyak-.html

6. [6] https://www.bloglistrik.com/2016/07/lightning-arrester-la.html Diakses pada Agustus 2019.

7. [7] Tobing, L. B. 2003 a. Peralatan Tegangan Tinggi. PT. Gramedia Pustaka Utama. Jakarta.

8. [8] Hajar, Ibnu. 2017. Kajian Pemasangan Lightning Arrester Pada Sisi Hv Transformator Daya Unit Satu Gardu Induk Teluk Betung. Jurnal Ilmiah Energi dan Kelistrikan Vol. 9 No. 2. Sekolah Tinggi Teknik PLN.

9. [9] Putra, R. 2018 Thermovisi Dalam Melihat Hot Point Pada Gardu Induk $150 \mathrm{Kv}$ Palur. Skripsi Mahasiswa Program Studi Teknik Elektro Universitas Muhammadiyah Surakarta.

10. [10]Putra, Julda. 2019 Analisis Pemeliharaan dan Penempatan Lightning Arrester Bay Bawen 2 Gardu Induk $150 \mathrm{kV}$ Klaten. Universitas Muhammadiyah Surakarta.

11. [11] PURNAWAN, I Made, dkk. 2016. Studi Pengaman Busbar Pada Gardu Induk Amlapura. Majalah Ilmiah Teknologi Elektro, vol. 15, no. 1, Hal. 38-41, Edisi Juni 2016. ISSN 2503-2372. doi: https://doi.org/10.24843/MITE.2016.v15i01p07. 